\title{
Intracellular muscle free amino acids-their measurement and function
}

By P. FÜRST, Institute for Biological Chemistry and Nutrition, University of Hohenheim, Garbenstrasse 30, D-7000 Stuttgart 70, Federal Republic of Germany

It is hoped that this presentation will focus attention and research upon the need to correlate nutrition more directly with the biochemistry of the individual tissue and cell. Such a focus, which is so essential to modern nutrition, must be considered as a way toward a more complete understanding of the dynamic system which forms the whole animal.

Muscle tissue is by far the most abundant cellular tissue in the body and is relatively uniform as to cellular composition. Profound biochemical changes in muscle are known to accompany electrolyte disorders, circulatory disturbances and nutritional deficiencies. In addition, morphological changes occur in certain muscle disorders and in generalized diseases. Biochemical and morphological studies of muscle tissue in man under various physiological and pathological conditions have proved to be of great value in clinical research and in the diagnosis of various diseases (Bergström, 1962; Edwards et al. 1973; Bergström, 1975).

\section{Sampling and analytical techniques}

Extensive studies of normal and pathological muscle metabolism require a simple method for muscle sampling. Percutaneous needle biopsy was introduced by Duchenne as early as 1868 for the investigation of patients with muscular dystrophy (Duchenne, 1868). The method seems, however, to have been little used until 1957, when it was suggested that percutaneous needle biopsy should be used for the study of muscle electrolytes in man in conjunction with neutron activation analysis (Reiffel \& Stone, 1957). Bergström (1962), using a new biopsy needle and a $5 \mathrm{~mm}$ incision in the thigh made under local anaesthesia, obtained samples of quadriceps of femoris muscle amounting to $30-100 \mathrm{mg}$ of tissue. This method of sampling is rapid and only slightly traumatic and can therefore be repeated several times in the same individual. Muscle function is usually little impaired immediately after the biopsy, as shown by the fact that subjects have been able to continue to compete in an $85 \mathrm{~km}$ cross-country ski race after several such biopsies (Bergström et al. 1973). Further improvements of the muscle biopsy technique have been made by Edwards et al. (1980). With the use of modern microanalytical techniques the biopsy sample can be analysed for water (Bergström, 1962), electrolytes (Bergström \& Friden, 1975), lipids (Bergström, 1962; Fröberg, 1973) and free amino acids (Bergström et al. 1974, 1976), as well as adenine nucleotides, creatine phosphate, creatine, glycolytic intermediates, glycogen and various enzymes (Harris et al. 1974).

The calculation of extra- and intracellular water is based on the chloride method, 
assuming a normal $(-87.2 \mathrm{mV})$ transmembrane potential according to Nernst's equation. Intracellular concentrations of free amino acids are then estimated based on intra- and extracellular water distribution. These calculations are described extensively elsewhere (Bergström et al. 1974, 1976). It has been shown that severe malnutrition and hypercatabolism may be associated with a decrease in membrane potential (Shires et al. 1970; Cunningham et al. 1971; Cotton et al. 1976). As direct measurements of the membrane potential are not made, a computer program was developed to evaluate the effect of a decreased potential on the water and free amino acid distributions (Fürst et al. 1977). In this equation the different variables (water, electrolytes and free amino acids) and the membrane potentials are expressed according to exponential functions and the transmembrane potential is used as a stepless variable from -50 to $-100 \mathrm{mV}$. It might be mentioned that errors in the calculation of the intracellular amino acid concentrations, introduced by not considering small differences in membrane potential, are negligible compared with the error of determination of the individual amino acids in muscle which might range from 4 to $9 \%$. The problems of using these calculations in severely catabolic patients have been discussed in detail (Bergström et al. I976, 1978, I981; Askanazi, Carpentier et al. 1980).

One problem inherrent in our present technique is the necessity to use different parts of the sample for amino acid, water and electrolyte measurements. Trials were made to use freeze-dried samples for determination of water, electrolytes and amino acids in one specimen. However, the measured water and chloride contents were found to be unreliable resulting in erroneously high amounts of extracellular water. No differences could be detected in free amino acid concentrations between rapidly frozen and homogenized samples (Kinney et al. I978), contrasting with the recent results of Milewski et al. (1982).

\section{Intracellular free amino acids in muscle in normal man}

It is known from animal experiments that the concentration of most free amino acids is much higher in cells than in extracellular fluid (Munro, 1970). Additionally, it is well-documented that during catabolism the distribution of free amino acids is altered between the extracellular and intracellular compartments (Fürst $e t$ al. 1977; Bergström et al. 1978; Askanazi, Carpentier et al. 1980; Askanazi, Fürst et al. 1980; Alvestrand et al. 1982; Milewski et al. 1982; Roth et al. 1982). Therefore, the plasma concentrations do not necessarily reflect the intracellular concentrations. Furthermore, there are considerable species differences in muscle amino acid concentrations (Munro, 1970; Fürst et al. 1977). Thus, while it is frequently possible to make qualitative conjectures about human metabolism from animal studies, a quantitative understanding requires direct measurements on man.

The intracellular pattern in normal man. We have used ion exchange chromatography for the determination of free amino acids in muscle tissue obtained by percutaneous needle biopsy (Bergström et al. 1974) and, for the first time, obtained reliable data on the intra- and extracellular concentrations of more 
than twenty-five amino acids in normal man and in patients suffering from various catabolic diseases before and after different therapeutic means. In normal man the majority of the amino acids had a much higher concentration in intracellular water than in plasma. The exceptions were the essential amino acids valine, leucine, isoleucine, phenylalanine and the non-essential amino acids citrulline and tyrosine with an intra-extracellular gradient below 2. The existence of a marked concentration gradient for some of the amino acids requires that free diffusion through the muscle fibre membrane be restricted. It is known that amino acids are actively transported into cells by different transport systems and thus require the expenditure of energy (Christensen, 1964). Therefore, the steady-state concentration of an individual amino acid in intracellular fluid and the concentration gradient across the cell membrane should be the combined effect of the affinity to the transport systems, the influence of other amino acids competing for carrier molecules, intracellular rate of production and utilization, extracellular supply and leakage rate across the cell membrane. It is also possible that certain amino acids are selectively concentrated in special areas in the cell, either by absorption to structural molecules or by accumulation in subcellular organelles. The fact that the intracellular amino acid pattern is reproducible from one individual to another suggests that the concentration of each individual amino acid in the cell is precisely regulated by biophysical and biochemical mechanisms.

The size of the intracellular amino acid pool. As skeletal muscle contains the largest pool of intracellular free amino acids, it is of interest to estimate the size of this pool (Table I). Direct determinations in man show that $\mathrm{I}$ kg skeletal muscle contains $230 \mathrm{~g}$ dry solids, $120 \mathrm{~g}$ extracellular water and $65^{\circ} \mathrm{g}$ intracellular water. The total free amino acid concentration in muscle was found to be approximately $35 \mathrm{mmol}(0.5 \mathrm{~g}) / 1$ intracellular water: taurine is additionally present at a concentration of $15 \mathrm{mmol} / 1$ and free carnosine at $6 \mathrm{mmol} / 1$. Of the total pool, the eight essential amino acids represent only $8.4 \%$. For a normal man with a body-weight of $70 \mathrm{~kg}$ and a muscle mass of $400 \mathrm{~g} / \mathrm{kg}$ body-weight, the total volume of intracellular muscle water is 18.21 ; thus, the total intracellular amino acid content can be estimated to be $86.5 \mathrm{~g}$.

Table 1. Composition of human muscle and the size of intracellular amino acid $(A A)$ pool

Dry solids
Extracellular water
Intracellular water $\left(\mathrm{H}_{2}\right.$

Intracellular free AA
Essential AA
Non-essential AA
Taurine
Carnosine

$(\mathrm{g} / \mathrm{kg})$
230
120
650
$\left(\mathrm{mmol} / 1 \mathrm{H}_{2} \mathrm{O}_{i}\right)$
35
3
32
15
6


Intracellular free amino acids in muscle in catabolic states-the unique pattern of catabolism

Free amino acid patterns in muscle have been measured in several catabolic conditions: in uremia (Bergström et al. 1978; Fürst et al. 1980; Alvestrand et al. 1982), diabetes mellitus (Roch-Nordlund et al. 1974), after major abdominal operations (Vinnars et al. 1975; Fürst et al. 1977; Vinnars, 1983) or after total hip replacement (Askanazi, Fürst et al. 1980), after severe injury (Fürst $e t$ al. I979; Askanazi, Carpentier et al. 1980), during sepsis (Askanazi, Carpentier et al. 1980), during experimental starvation (Elwyn et al. 1981) or semi-starvation (Askanazi et al. 1978) and during immobilization (Askanazi et al. 1978). One important finding is that the concentrations of free amino acids in muscle change in response to changes in diet and physiological and pathological states (Fürst et al. 1977). Each catabolic condition appears to have its own unique and reproducible intracellular pattern. Valine, like the other branched-chain amino acids (BCAA), increases in trauma and during starvation but is unchanged in diabetes. Glutamine, by contrast, decreases considerably in trauma and starvation but is unchanged in uremia and diabetes. In chronic uremia, selective decreases in valine and threonine are consistent findings. Changes in plasma free amino acid concentrations may parallel those in muscle, but frequently differ either quantitatively or qualitatively. These results indicate that the intracellular free amino acid pattern of muscle is characterized by a 'unique pattern of catabolism' distinctive for the disease or condition studied.

\section{Interpretations and hypotheses}

Protein synthesis, breakdown and the free amino acid pool. The interpretation of changes in free amino acids in muscle must rest on their role in protein synthesis and breakdown. The total body pool of free amino acids is above $120 \mathrm{~g}$, only $\mathrm{I} \%$ of the total protein pool and amounts to about $30 \%$ of the daily protein turnover, assumed to be approximately $400 \mathrm{~g} / \mathrm{d}$ (Munro \& Thompson, 1953). These figures would suggest that there are sufficient amounts of free amino acids in the total body pool to sustain the normal rate of protein synthesis for at least $7 \mathrm{~h}$. However, when the breakdown of the individual amino acids is considered, this calculation is misleading. Table 2 exemplifies the distribution of selected amino acids between extra- and intracellular water and the sum of essential and non-essential amino acids in the respective compartments. The BCAA are present in similar concentrations in cell and plasma, whereas the non-essential amino acids are more highly concentrated in cells. Considering the distribution of amino acids in mixed muscle protein (Fürst et al. 1970) (column 4, Table 2), it is very different from that in the free amino acid pool (column 3 ). Consequently, there is a large difference in the availability of individual amino acids for protein synthesis. One may calculate this difference as the length of time protein synthesis could continue before it uses up all the free amino acids in the total body pool, assuming that the rate of protein synthesis is $400 \mathrm{~g} / \mathrm{d}$. As calculated, the availability of the BCAA is considerably 
Table 2. The estimated distribution of selected amino acids $(A A)$ as well as essential and non-essential $A A$ between extra- and intracellular water. The calculation of $A A$ turnover time is based on the availability of individual free $A A$ in the total body water assuming a daily protein turnover of $400 \mathrm{~g} / d$ and considering the distribution of individual $A A$ in mixed tissue protein

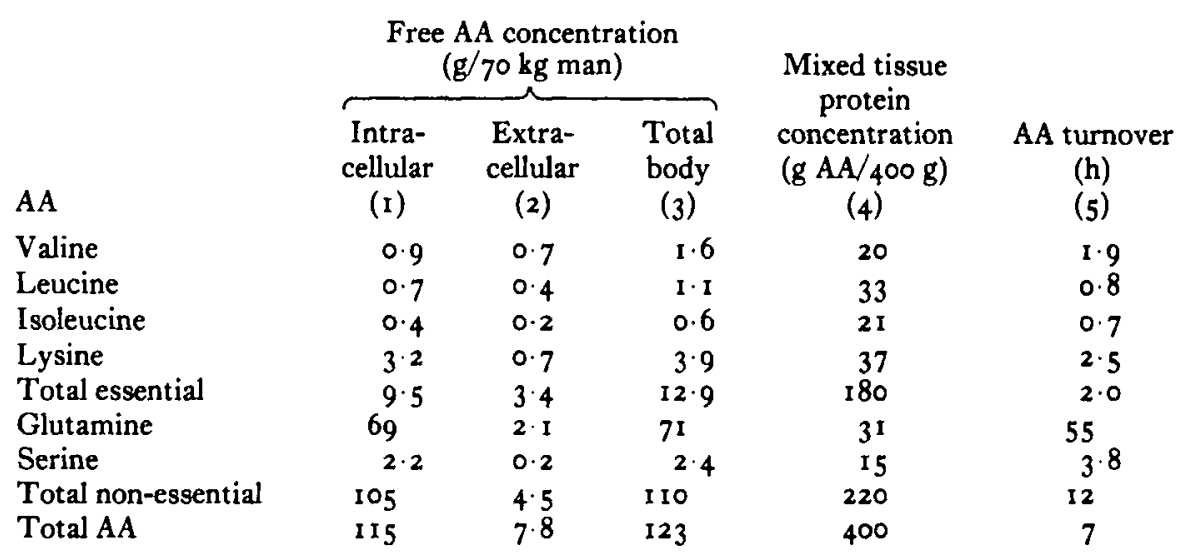

less than those of non-essential amino acids or lysine (column 5). This means that alterations in the rates of protein synthesis or breakdown in any organ or tissue cannot continue for more than a few minutes unless there are compensatory changes in other organs, involving changing rates of net protein synthesis, amino acid catabolism or of dietary amino acid supply.

Selective intracellular alterations-tentative explanations. Bedrest (immobilization), starvation, semi-starvation, postoperative trauma, severe injury and onset of sepsis are conditions associated with negative nitrogen balance which is presumed to originate largely from net protein degradation in skeletal muscle. The negative balance varies in extent from $-1 \mathrm{~g} \mathrm{~N} / \mathrm{d}$ on bedrest up to -20 to -40 $\mathrm{g} \mathrm{N}$ or more per day in severe injury and sepsis. This means that in each of these conditions there is a net transport of amino acids out of muscle. The pattern of changes in amino acid concentrations in muscle and plasma show many similarities during catabolism. In all cases there is an increase in BCAA, aromatic amino acids and methionine and a decrease in glutamine and in basic amino acids. Regarding the changes observed in neutral amino acids, there is gradation of response, with minimal changes seen in muscle with bedrest and maximal changes in sepsis, as illustrated in Fig. I. In the milder conditions, increases of BCAA are proportionally greater than those in the aromatic amino acids and methionine, while in severe injury and sepsis they are less. It is also notable that, in the milder conditions, plasma concentrations of BCAA rise proportionally to intracellular conditions, but in severe catabolic states increased intracellular BCAA concentrations are not accompanied by similar rises in plasma concentrations.

A uniform reduction of approximately $50 \%$ in free glutamine in muscle seems to be one of the most typical features of the response to starvation (Elwyn et al. 1981) 

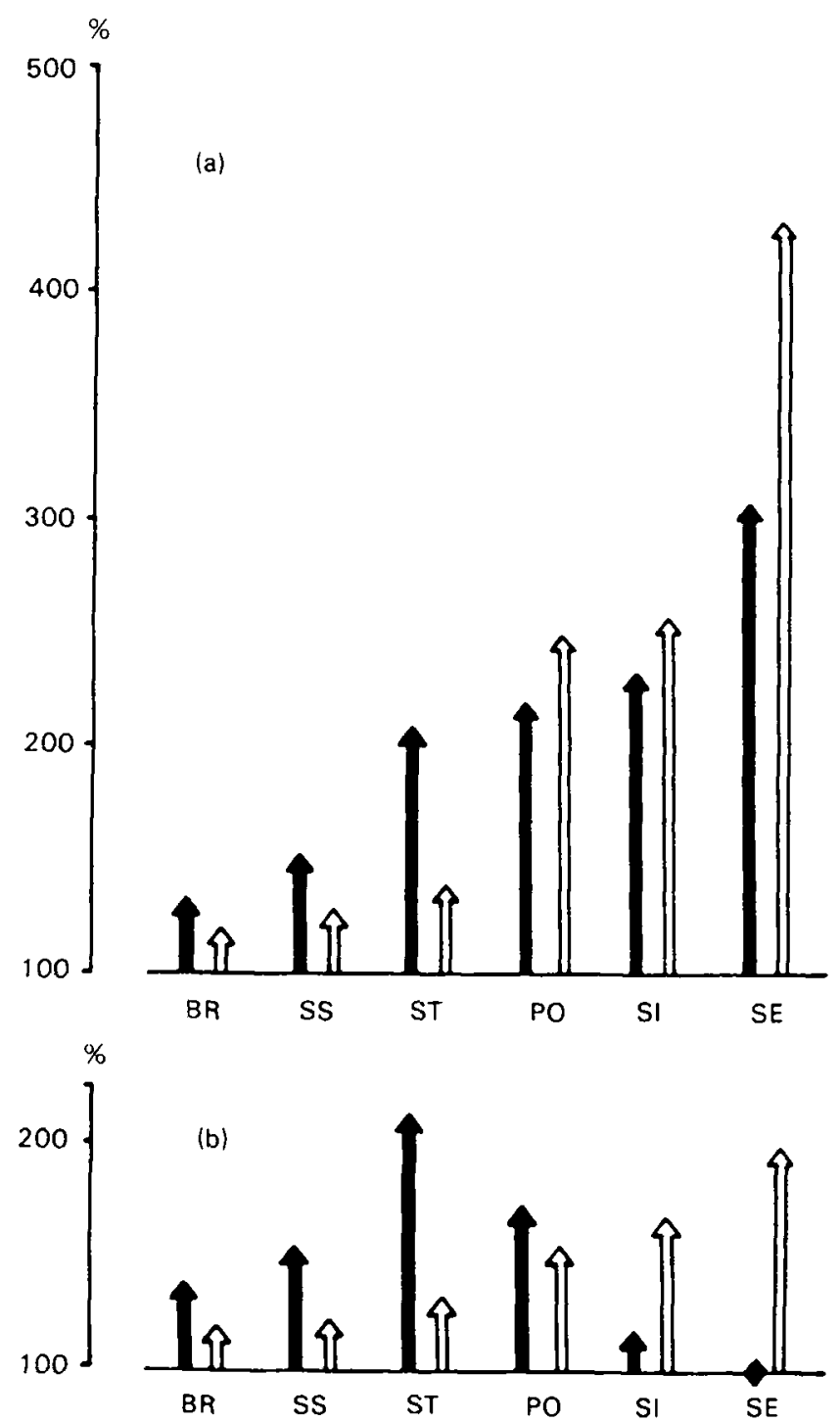

Fig. I. Branched-chain amino acids $(\uparrow)$ and aromatic amino acids and methionine $(\widehat{S})$ in (a) muscle and (b) plasma as affected by catabolism (\% changes from normal). BR, bedrest; SS, semi-starvation; ST, starvation; PO, postoperative trauma; SI, severe injury; SE, sepsis.

and trauma (Vinnars et al. 1975; Fürst et al. 1977, 1979; Askanazi, Carpentier et al. 1980; Askanazi, Fürst et al. 1980; Milewski et al. 1982; Roth et al. 1982; Vinnars, 1983) irrespective of dietary regimen or the extent of injury. While the majority of the intracellular amino acid concentrations returned to or toward normal levels during late convalescence, intracellular glutamine continued to be reduced by $50 \%$ (Askanazi, Carpentier et al. 1980): this particular abnormality is very difficult to correct and seems to be a consistent quantitative response of the catabolic state. In late convalescence, the low glutamine concentration could be 
due to inadequate nutrition. Inadequate nutrition in the late convalescent phase may also explain the slightly decreased intracellular arginine and lysine concentrations, since these amino acids showed very similar responses during starvation (Elwyn et al. $198 \mathrm{r}$ ) and immobilization plus semi-starvation (Askanazi et al. 1978).

Increased tissue catabolism alone cannot explain the observed intracellular amino acid pattern, since certain amino acids show no change or reveal a decreased concentration. However, the alterations may be explained in terms of specific amino acid transport systems. The BCAA together with phenylalanine, tyrosine and methionine are transported by the leucine-preferring system (L-transport system) (Christensen, 1969). It is postulated that the system becomes limiting and that higher efflux requires higher intracellular concentrations. This helps to explain the finding that intracellular concentrations as well as transmembrane gradients increase with increasingly negative $\mathrm{N}$ balance. In most severe catabolic states, net proteolysis in muscle is much greater and there are four-fold increases in muscle concentrations of the aromatic amino acids and methionine (Askanazi, Carpentier et al. 1980; Roth et al. 1982). The liver's ability to handle this outflow will be taxed, leading to increase in plasma concentrations. If the L-transport system is limiting in severe catabolic states, the high muscle concentrations of aromatic amino acids and methionine will competitively reduce the outflow of BCAA; thus plasma concentrations of $\mathrm{BCAA}$ will decrease with respect to those in muscle.

\section{The effect of nutrition on free intracellular amino acids in muscle}

Postoperative trauma, severe injury and sepsis. To provide an optimal nutritional regimen for a wide variety of disease states is perhaps the most demanding task for the clinician. It is, however, by no means clear what are the ideal compositions and/or optimal amounts of the amino acids required. Occasionally, it is even questioned whether provision of amino acids is beneficial during the early period of increased protein loss (Moore \& Brennan, 1975). In recent years the benefits of special amino acid mixtures for a particular disease or condition has been claimed. A growing body of experimental and clinical evidence emphasizes the special importance of BCAA as solitary therapeutical agents in various catabolic disorders. The fundamental question is whether a unique composition of nutrients is ever required.

In current studies intracellular (muscle) free amino acids were repeatedly measures after elective operations (Vinnars, 1983) and after severe accidental injury and burns (Fürst et al. 1979; Vinnars et al. 1983). The effect of different parenteral regimens with different amounts and proportions of amino acids were evaluated in the immediate post-injury phase. The pattern of trauma was apparently not influenced by parenteral nutrition. Alterations in the individual amino acid concentrations appeared not to be influenced by the total amounts or mixtures of amino acids given. Surprisingly, the high amounts of amino acids given were not reflected in an increased amino acid pool in muscle and a sustained decrease in muscle glutamine concentration was found in all patients. 
It is interesting to note that while the increases in leucine and isoleucine levels were similar, valine concentration was increased less during parenteral nutrition (Vinnars, 1983). It is generally assumed that the same unspecific BCAA transaminase is responsible for the degradation of all three BCAA (Ichihara \& Koyama, I 966$)$ and that a single dehydrogenase complex controls the rate-limiting decarboxylation of the branched-chain keto acids (Odessey \& Goldberg, 1972). A specific handling of valine, however, is repeatedly demonstrated in uremia (Fürst et al. 1980; Alvestrand et al. 1982) and in liver disease (Madsen, 1983). It cannot be excluded that operative trauma may induce a different response of valine compared with the other BCAA. This might be supported by the demonstration of metabolic defects involving only one or two of the BCAA in man (Budd et al. 1967), suggesting that decarboxylation of branched-chain keto acids may occur by more than one enzymic mechanism (Connelly et al. 1968).

It has been repeatedly suggested that BCAA inhibit the flux of amino acids from muscle, effectively decreasing muscle breakdown and that the rate of BCAA oxidation determines the rate of overall protein catabolism (e.g. see Odessey et al. 1974). There has also been speculation that in sepsis and in severe trauma, muscle oxidizes BCAA to compensate for an energy deficit caused by a reduced supply of metabolizable energy (Ryan et al. 1974; O'Donnel et al. 1976; Moldawer et al. 1983). These theories must assume reduced intracellular BCAA concentrations but direct measurements reveal considerable increases in BCAA levels in the cells with unchanged or reduced plasma concentrations. This suggests that changes in BCAA do not mediate but rather result from changes in protein synthesis.

The above findings may indicate that BCAA are being used for protein synthesis by the viscera. Moreover, increased lipolytic rate as well as increased oxidation of exogenous fat was recently demonstrated (Carpentier et al. 1979), suggesting a preferential use of fat for energy. Furthermore, in recent investigations we were able to show that severe trauma and sepsis were associated with tissue depletion of energy-rich compounds and that the cellular energy level was decreased (Liaw et al. 1980,1982$)$. The combination of a tissue energy deficit and the observed accumulation of intracellular BCAA thus suggests an impairment of substrate use, rather than a lack of fuel available to the cell. It is becoming clear that nutrition at the height of the flow phase after injury requires further detailed study.

Chronic renal failure. In untreated uremic patients, a unique intracellular pattern was observed (Bergström et al. 1978; Fürst et al. I980; Alvestrand et al. I982): typical features are low intracellular concentrations of valine, threonine, tyrosine and high levels of argninine, ornithine and citrulline. In patients treated with a low-protein diet, supplemented with an amino acid mixture of essential amino acids in the proportions recommended by Rose (1949), the distribution of the BCAA was found to be abnormal, with low intra- and extracellular valine concentrations but normal or high intracellular and low plasma levels of leucine and isoleucine (Fürst et al. 1980; Alvestrand et al. 1981, 1982). Excess or deficiency of one of the BCAA might, therefore, change the distribution of the others and be associated with deterioration of growth and diminished amino acid utilization (Harper, 1964). 
The abnormal distribution of BCAA persisted even though the regimen provided 3-4 times the minimum requirement of valine. This observation indicates that uremic patients may require BCAA in different proportions to non-uremic individuals. A new amino acid formula was composed and long-term treatment resulted in improved $\mathrm{N}$ balance (Fürst et al. 1980; Alvestrand et al. 1983). The results suggest that normalization of amino acid pools may improve $\mathrm{N}$ utilization.

\section{Interpretation of amino acid patterns}

Successful normalization or partial correction of an abnormal plasma amino acid pattern is often taken as a guarantee of adequate amino acid utilization. However, the limitations inherent in methodology and in data interpretation are sadly often neglected. There are many factors which influence amino acid concentrations (for review see Fürst, 1983). Diurnal variation, previous nutrition, physical activity and technical errors should be considered. Age and sex are two further important factors affecting amino acid concentrations (Möller et al. 1979, 1983). Measurements of free amino acids are usually made at a single point in time and an adequately controlled data base is of the utmost importance in deciding whether a subject manifests normal or abnormal amino acid metabolism. In Fig. 2, patients revealed a normal level of plasma valine when compared with healthy controls but the value was significantly and markedly reduced when the comparison was made with age- and sex-matched controls. In contrast, an apparently increased value for muscle lysine was in reality normal when age- and sex-matched controls were used for comparison. Thus, age- and sex-related differences in amino acid and electrolyte concentrations may explain the considerable inter-subject variation found by some investigators.

Finally, an essential question to ask is how to identify a pathological amino acid profile and whether the therapeutic intention should be to normalize, by whatever means, the pathological pattern. It is worth striving to achieve a normal pattern if the high or low values are due to an amino acid imbalance. Intracellular depletion of amino acids is always a sign of deficiency and thus might be corrected. Increase in the amino acid concentrations, without obvious presence of a concomitant imbalance, is, however, difficult to interpret and further investigations are therefore warranted.

\section{Conclusions and future aspects}

Imbalance of cellular amino acids may be one of the fundamental factors adversely affecting protein synthesis. Our results indicate either that the proportions in presently-available solutions are not suitablc or that these solutions are incomplete, since important amino acids such as glutamine, tyrosine and cystine are not included. These amino acids are either insoluble or unstable during heat sterilization. Recently, three peptides containing glutamine, tyrosine and cystine respectively have been synthesized in our laboratory, which are highly soluble, stable and cellularly cleavable (Stehle, Kühne et al. 1982; Stehle, Pfaender 


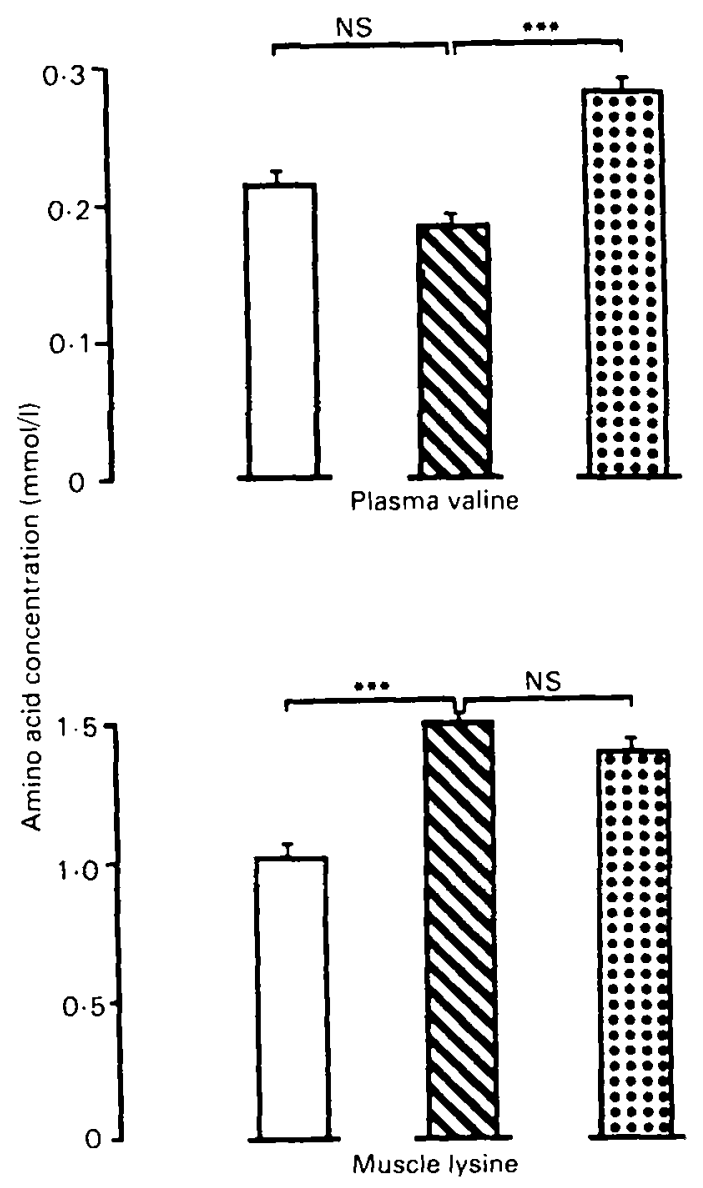

Fig. 2. The amino acid concentrations in plasma and muscle as a function of sex and age in chronic uremic patients $(\mathbb{S})$ compared with results derived either from mixed healthy controls $(\square)$ or from age- and sex-matched controls (®). NS, not significant; $* P<0.001$. Results adapted from Alvestrand et al. (1982).

et al. 1982). Studies are going on which may prove that the inclusion of such peptides will improve $\mathrm{N}$ utilization.

A better understanding of the factors affecting protein synthesis and breakdown is significant not only from a theoretical standpoint: it also has important practical implications if it can lead to a reduction of catabolic losses and optimization of protein gains during repletion therapy.

We believe that determination of intracellular amino acid patterns before and during therapy provides a powerful tool in developing better nutritional techniques during catabolic stress, when the method is correctly implemented and interpreted. 


\section{REFERENCES}

Alvestrand, A., Ahlberg, M., Bergström, J. \& Fürst, P. (1981). In Metabolism and the Clinical Implications of Branched-Chain Amino and Ketoacids, p. 547 [M. Walser and J. R. Williamson, editors]. New York: North-Holland/Elsevier.

Alvestrand, A., Ahlberg, M., Bergström, J. \& Fürst, P. (1983). Clin. Nephrol. 19 (2), 67.

Alvestrand, A., Bergström, J. \& Fürst, P. (1982). Clin. Nephrol. 18 (6), 297.

Askanazi, J., Carpentier, Y. A., Michelsen, C. B., Elwyn, D. H., Fürst, P., Kantrowitz, L. R., Gump, F. E. \& Kinney, J. M. (1980). Ann. Surg. 192, 78.

Askanazi, J., Elwyn, D. H., Kinney, J. M., Gump, F. E., Michelsen, C. B., Stinchfield, F. E., Fürst, P., Vinnars, E. \& Bergström, J. (1978). Ann. Surg. 188, 797.

Askanazi, J., Fürst, P., Michelsen, C. B., Elwyn, D. H., Vinnars, E., Gump, F. E., Stinchfield, F. E. \& Kinney, J. M. (1980). Ann. Surg. 19r, 465.

Bergström, J. (1962). Scand. F. clin. Lab. Invest. 14, Suppl. 68.

Bergström, J. (1975). Scand. F. clin. Lab. Invest. 35, 609.

Bergström, J., Alvestrand, A., Fürst, P., Hultman, E., Sahlin, K., Vinnars, E. \& Widström, A. (1976). Clin. Sci. Mol. Med. 51, $5^{89}$.

Bergström, J. \& Fridén, A.-M. (1975). Acta med. scand. 197, 4 I 5.

Bergström, J., Fürst, P., Holmström, B., Vinnars, E., Askanazi, J., Elwyn, D., Michelsen, C. B. \& Kinney, J. (1981). Ann. Surg. 193, 810.

Bergström, J., Fürst, P., Norée, L.-O. \& Vinnars, E. (1974). F. appl. Physiol. 36, 693.

Bergström, J., Fürst, P., Noré, L.-O. \& Vinnars, E. (I978). Clin. Sci. Mol. Med. 54, 51 .

Bergström, J., Hultman, E. \& Saltin, B. (1973). Int. Z. angerv. Physiol. 31, $7^{1}$.

Budd, M. A., Tanaka, K., Holmes, L. B., Efron, M. L., Crawford, J. D. \& Isselbacher, K. J. (1967). N. Engl. F. Med. 277, 32 I.

Carpentier, Y. A., Nordenström, J., Askanazi, J., Elwyn, D. H., Gump, F. E. \& Kinney, J. M. (1979). Surg. Forum 30, 72.

Christensen, H. N. (1964). In Mammalian Protein Metabolism, vol, I, p. I [H. N. Munro and J. B. Allison, editors]. New York: Academic Press.

Christensen, H. N. (1969). Adv. Enzymol. 32, I.

Connelly, J. L., Danner, D. J. \& Bowden, J. A. (1968). F. biol. Chem. 243, i 198.

Cotton, J. T., Carter, N. W. \& Knochel, J. P. (1976). In Abstracts of the 9 th Annual Meeting of the American Society of Nephrology, p. 29.

Cunningham, J. N. Jr, Carter, N. W., Rector, F. C. Jr \& Seldin, D. W. (1971). F. clin. Invest. 50, 49.

Duchenne, G. B. (1868). Arch. gén. Méd. II, I 79.

Edwards, R. H. T., Maunder, C., Lewis, P. D. \& Pearse, A. G. E. (1973). Lancet ii, 1070.

Edwards, R. H. T., Young, A. \& Wiles, M. (1980). New Eng. F. Med. 302, 261.

Elwyn, D. H., Fürst, P., Askanazi, J. \& Kinney, J. M. (I98I). In Metabolism and Clinical Implication of Branched-Chain Amino and Ketoacids, p. 547 [M. Walser and J. R. Williamson, editors]. New York: North-Holland/Elsevier.

Fröberg, S. O. (1973). Acta med. scand. 194, 553.

Fürst, P. (1983). In Nero Aspects of Clinical Nutrition, p. 361 [G. Kleinberger and E. Deutsch, editors]. Basel: Karger.

Fürst, P., Alvestrand, A. \& Bergström, J. (1980). Am. F. Clin. Nutr. 33, I387.

Fürst, P., Bergström, J., Chao, L., Larsson, J., Liljedahl, S.-O., Neuhauser, M., Schildt, B. \& Vinnars, E. (1979). Acta Chir. Scand. 494, ${ }^{1} 3^{6}$.

Fürst, P., Bergström, J., Kinney, J. M. \& Vinnars, E. (1977). In Nutritional Aspects of Care of the Critically Ill, p. $3^{89}$ [J. E. Richards and J. M. Kinney, editors]. Edinburgh: Churchill Livingstone.

Fürst, P., Jonsson, A., Josephson, B. \& Vinnars, E. (1970). F. Appl. Physiol. 29, 307.

Harper, A. E. (1964). In Mammalian Protein Metabolism, vol. II, p. 87 [H. N. Munro and J. B. Allison, editors]. New York: Academic Press.

Harris, R. C., Hultman, E. \& Nordesjö, L.-O. (1974). Scand. F. clin. Lab. Invest. 33, tog.

Ichihara, A. \& Koyama, E. (1966). 7. Biochem. 59, I60.

Kinney, J. M., Fürst, P., Elwyn, D. H., Askanazi, J. \& Vinnars, E. (1978). Technical report no. GM 14546. Washington DC: National Institute of Health. 
Liaw, K. Y., Askanazi, J., Michelsen, C. B., Fürst, P., Elwyn, D. H. \& Kinney, J. M. (I982). Ann. Surg. $195,12$.

Liaw, K. Y., Askanazi, J., Michelsen, C. B., Kantrowitz, L. R., Fürst, P. \& Kinney, J. M. (I980). J. Trauma 20, 755 .

Madsen, D. C. (1983). In Advances in Clinical Nutrition, p. 3 [I. Johnston, editor]. New York: MTP Press.

Milewski, P. J., Threlfall, C. J., Heath, D. F. \& Irving, M. (1982). Clin. Sci. 62, 83.

Moldawer, L. L., Echenique, M. M., Bistrian, B. R., Duncan, J. L., Martin, R. F., St. Lezin, E. M. \& Blackburn, G. L. (1983). In Advances in Clinical Nutrition, p. 65 [D. A. Johnston, editor]. New York: MTP Press.

Möller, P., Alvestrand, A., Bergström, J., Fürst, P. \& Hellström, K. (1983). Gerontology 29, I.

Möller, P., Bergström, J., Eriksson, S., Fürst, P. \& Hellström, K. (1979). Clin. Sci. 56, 427.

Moore, F. D. \& Brennan, M. R. (1975). New Eng. F. Med. 293, 194.

Munro, H. N. [editor] (1970). In Mammalian Protein Metabolism, vol. 4, p. 299. New York: Academic Press.

Munro, H. N. \& Thompson, R. S. T. (1953). Metab. clin. Exp. 2, 354.

Odessey, R. \& Goldberg, A. L. (1972). Am. F. Physiol. 22, 1 376.

Odessey, R., Khairallah, E. Z. \& Goldberg, A. (1974). F. biol. Chem. 249, 7623.

O'Donnell, T. F. Jr, Clowes, G. H. A. Jr \& Blackburn, G. L. (1976). Surgery 80, 192.

Reiffel, L. \& Stone, C. A. (1957), F. Lab. clin. Med. 49, 286.

Roch-Nordlund, A. E., Alinder, A., Ahlberg, M., Fürst, P. \& Werner, G. (1974). Acta Endocrinol. 77, 190.

Rose, W. (1949). Fedn Proc. Fedn Am. Socs exp. Biol. 8, 546.

Roth, E., Funovics, J., Mühlbacher, F., Schemper, M. \& Mauritz, W. (1982). Clin. Nutr. I, 25.

Ryan, N. T., Blackburn, G. L. \& Clowes, G. H. A. Jr (1974). Metabolism 23, ro8r.

Shires, G. T., Carrico, C. J., Baxter, C. R., Giesecke, A. H. \& Jenkins, M. J. (1970). In Advances in Surgery, vol. 4, p. 255 [C. E. Welch, editor]. Chicago: Yearbook Medical Publisher Inc.

Stehle, P., Kühne, B., Kubin, W., Fürst, P. \& Pfaender, P. (1982). J. Appl. Biochem. 4, 280.

Stehle, P., Pfacnder, P. \& Fürst, P. (1982). F. Chromatogr. 249, 408.

Vinnars, E., Bergström, J. \& Fürst, P. (1975). Ann. Surg. 163, 665.

Vinnars, E. (1983). In New Aspects of Clinical Nutrition, p. 422 [G. Kleinberger and E. Deutsch, editors]. Basel: Karger.

Vinnars, E., Holmström, B., Schildt, B., Odebäck, A.-C. \& Fürst, P. (1983). Clin. Nutr. 4. (In the Press.) 